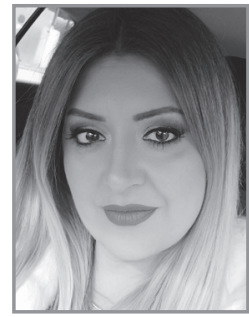

Marija BORANIJAŠEVIĆ

Academy of Technical

and Educational Applied Studies

Niš

CONTACT: marijaboranijasevic@yahoo.com

\title{
THE SERBIAN LANGUAGE AND CYRILLIC IN EVERYDAY LIFE AND THE MEDIA
}

Abstract: The subject of research in this paper is the use of the Serbian language and Cyrillic in everyday life, as well as in the media. The contemporary way of life and modern trends largely affect the Serbian language and use of Cyrillic because of the omnipresence of English in all the spheres of our lives, the influence of which has led to the phenomenon called language Anglo-globalization. It seems that Serbian, under the strong influence of English, is gradually changing, and not only does this change happen in the sphere of everyday life but also in all the spheres of professional life as well. Besides the ubiquitous influence of English that is mirrored in the names of companies, stores, cafés etc., another problem has occupied out attention, and that is a very limited use of Cyrillic in both everyday life and the media. The subject of analysis were the names of cafés and the presence of Cyrillic in them and the use of Cyrillic in the media - the daily newspapers and TV channels. The results show that Cyrillic is used rather limitedly, while Latin alphabet has the priority both in everyday life and the media.

Keywords: THE ENGLISH LANGUAGE, THE SERBIAN LANGUAGE, EVERYDAY LIFE, THE MEDIA, CYRILLIC, LATIN ALPHABET. 


\section{Introductory Thoughts}

Language and writing represent the essential and most prominent characteristics of every people and every culture. Therefore, it should be carefully treasured and treated with respect.

"Under the notion of a unique language of humankind should be taken the fact that all humans use language" (Bugarski, 1972: 19).

Language is a basic instrument of human communication since

"human communication implies the existence of individuals who have a common symbolic system, who are capable of coding and decoding that system and whose code behavior is systematically under the influence of a communication situation. This common symbolic system is language and it significantly differs from the systems of communication of other species" (Janićijević, 2000: 113).

Language could be defined in many different ways. However, what represents the basic characteristic of every language, and therefore appears in every different definition, is that language is a symbolic system in the first place, then it is a social phenomenon, and finally it represents means of communication immanent to humans as species.

"Language is not only a symbolic system that humans use the most but it is also the most developed symbolic system of all. It possesses the characteristics of every symbolic system, but also those which are the characteristics of language as a specially designed system of symbols" (Rot, 2004: 37).

It also

„makes a basic connection among people on which, due to the nature of humans as social beings, depends the very existence of human communities" (Bugarski, 1996: 25).

Language, a concrete manifestation of speech as a general ability immanent to all people, is prone to constant changes.

"Language appears, survives and evolves in a continuous interaction with the world it depicts, and this is a total human experience. It is not only a peculiar mirror of a person's relationship towards this world, society and themselves, but also 


\section{Marija BORANIJAŠEVIĆ}

Academy of Technical and Educational Applied Studies

a form of a creative human act during which both the language and the world change" (Bugarski, 1996: 13).

Languages and their writings have experienced certain modifications through history. A standard literary language in one country, or in more countries (the example of German which is an official language in Germany, Austria and a part of Switzerland), represents a common characteristic of different dialects that may appear in one language. In China, for instance, the same system of writing has survived for about 4000 years. So, while the dialects of certain areas in this huge country differ to the extent of mutual non-understanding between the citizens of this country, the writing connects them. Therefore, they can communicate in writing without difficulty.

With some other languages, on the other hand, both the writing and orthography keep changing. Language changes in space and time, so

„traditional orthographies, once set, cannot keep up with these changes; this is the reason why most of today's orthographies show considerable deviations from the phonemic principle, which in every separate case at the times of the adjustment of the alphabet and the constitution of written language was incomparably more prominent" (Bugarski, 1983: 230-231).

The Serbian language, as opposed to some other European languages like English or French the orthography of which seems to be pretty confusing, does not show any significant deviations concerning the literary language and orthography either in space or time. This fact is a consequence of a relatively recent reform of Vuk Stefanović Karadžić, unlike the mentioned languages the orthography of which would truly depict the speech that used to be used a few hundred years ago, since there has not been performed any new reform of the writing and orthography. The times to come are to prove whether our seemingly perfect writing in which one orthographic sign corresponds to one phoneme will be able to resist the changes and keep its inviolable status. Taking into account the habits of the young population in the Republic of Serbia, at least when it comes to informal correspondence, the predictions do not seem to be very optimistic. 


\section{The Serbian Language and Cyrillic in Everyday Life}

The younger population in Serbia today is constantly under a strong influence of the media and the English language.

This fact undoubtedly affects the language they use in everyday life, and all this due to the phenomenon of language Anglo-globalization which has resulted in the appearance of the so-called Anglo-Serbian language which keeps deviating from the norms of the Serbian language and continues being used according to the norms of the English language (Prćić, 2005: 69).

„Let us call it either Anglo-Serbian or Newserbian, this hybrid language represents our reality and unless, as native speakers of the Serbian language, we do not affect the collective consciousness regarding this issue, this spontaneous phenomenon may as well result in creation of Newserbian" (Boranijašević, 2018a: 158).

Sometimes parents and their children seem to speak different languages. Parents often find it very difficult to understand the slang their children use in their communication with their peers. Non-understanding is even highlighted in a written form, the short messages they communicate in the social media, for instance. It seems that the speed of contemporary life is reflected in the economy of language that is spotted here. Therefore, the communication of the young is short, poor in vocabulary, full of abbreviations known only to them and it abounds in the aforementioned Anglo-Serbian words.

Let us also mention the very writing. Cyrillic is the only official writing in the Republic of Serbia according to the Constitution of the Republic of Serbia which states: "In the Republic of Serbia in official use are the Serbian language and Cyrillic" However, it rarely represents the first choice of the young. Moreover, even when using Latin alphabet, they almost as a rule use the English alphabet. As a result, there are no diacritical signs in their writings, and therefore no letters such as č, ć, š or ž. This way they distort the Serbian words containing these letters, creating something that can eventually become a part of a new orthography in the already mentioned possible variant of Serbian - Newserbian. It most certainly takes time to change a language. Nevertheless, such changes are possible and have been happening during history. And, as we all know, a continuously repeated lie can easily become the truth. Analogously, a continuously repeated mistake may become a rule. Variety of different fonts is widely available, so the only conclusion that is imposed is that only laziness and negligence are to blame for this persisting phenomenon which is slowly spreading

1 The Constitution of the Republic of Serbia, article 10, Language and Writing, "Službeni glasnik RS”, 98/2006. 


\section{Marija BORANIJAŠEVIĆ}

Academy of Technical and Educational Applied Studies

Niš

outside the modern technology and keyboard use. Therefore, we often happen to be witnesses of it being present in handwritten texts as well, which is absurd. Moreover, the orthography comes last and punctuation is completely marginalized. One would say that it is only informal communication and as such does not represent a big of a problem. However, this kind of trend is reflected in their communication in general. We have witnessed it in writing in exam and term papers, and not once.

What should also be mentioned is the fact that young people nowadays are very often functionally illiterate; they are, for instance, incapable of fulfilling a form or a payment slip. While successfully using all the different kinds of social networks, when they show sufficient digital knowledge when it comes to uploading a photo, liking someone's status or being informed at any moment about popular events, most of them are incapable of composing and sending a correct email, since in a very high percentage of emails there is either the subject missing or the cover letter. They just attach a term paper or homework and send the email. One cannot but ask a question whether this is a more serious problem or the one when there is a cover letter which, unfortunately, shows a serious lack of elementary knowledge of the language rules, as well as social and cultural norms.

The large influence of English may be seen not only in people's everyday conversation but also in other aspects of everyday life. This aspect is mirrored, for example, in the names of cafés, restaurants and companies and private businesses. Here is the list of some of the cafés in Niš which is to illustrate the point mentioned above. In the first column there are the names which can be considered Serbian, in the second those that have English names, in the third there are the names of cafés that show a strange mixture of Serbian and English, while the fourth column presents the names of the cafés which belong to neither of the three mentioned categories; they either contain words belonging to other languages or they contain incorrectly spelled English words, incorrect spelling appearing very often.

\begin{tabular}{|c|c|c|c|}
\hline SERBIAN NAMES & ENGLISH NAMES & MIXED NAMES & OTHER \\
\hline KLUB RASKRŠĆE & SUNSET CLUB & MODA CAFE & CAFFE MOVIES \\
\hline ETNO SCENA & SYMPHONY CLUB & CAFE FAMA & CAFFE CAFFE \\
\hline TRAMVAJ & DIVINE CAFE & EURO GORČA & CAFFE PARADIZZO \\
\hline DOM PLANINARA & HEDONIST CAFE & FLERT CAFE & CAFFE BULEVAR \\
\hline BAKINA KUĆA & GREEN BAR & SALOON TRVĐAVA & CAFFE FACE \\
\hline JORGOVAN MALA & SPARK MUSIC CLUB & & CAFFE BOMBAY \\
\hline NA ĆOŠKU & NEST & & CAFFE BROZ \\
\hline KAFETERIJA & SIMPLY & & CREM CAFFE \\
\hline & VANILLA CAFÉ & & SPLAV PORTO BELLO \\
\hline & CAFE PASSAGE & & \\
\hline
\end{tabular}


These names of the cafés were to illustrate the influence of English and presence of Latin alphabet. As we can notice, quite a few names of cafés are in English, some of which are in a strange mixture of English and Serbian, while a considerable number of the names are either a mixture of Serbian and English or other languages, while containing prominent errors in spelling. For instance, the word café is misspelled a number of times as caffe, which represents more of a rule than an exception. Moreover, it can be noticed that only in the name of Vanilla Café the very word is spelled correctly, while in all the other examples of the English names, the diacritical sign has been omitted. Finally, only minority of all the names are in Serbian, only two of which being in Cyrillic ( $N a$ ćošku and Kafeterija).

It should be mentioned that the influence of English is widely present in the names of the stores or companies, not to mention that Latin alphabet is almost exclusively used. For example, the two probably biggest book stores and publishers of fiction in the Republic of Serbia, Vulkan and Laguna, not only have their names spelled in Latin alphabet, but also have most of their editions printed in Latin alphabet as well.

The method of random sample concerning the names of stores in Niš also proves the prevalence of Latin alphabet, not to mention that a large majority of the names are in English. The table below is to show this point.

\begin{tabular}{|c|c|}
\hline CYRILLIC & LATIN ALPHABET \\
\hline PEKARA BRANKOVIĆ & CEZAR - DIFFERENT FAST FOOD \\
\hline POKLON DUĆAN & LUCKY WIN SLOT CLUB \\
\hline AS TRGOVINA & T GROUP - WATCHES AND JEWELS \\
\hline HIJEROGLIF & SILVER SHOP \\
\hline \multirow[t]{14}{*}{ PEKARA BRAŠKO } & PINK MOBILE \\
\hline & THE BODY SHOP \\
\hline & LUNA \\
\hline & DUŠAN STIL \\
\hline & KATRIN \\
\hline & OPPOSITE SHOES AND BAGS \\
\hline & METRO \\
\hline & BEBAKIDS \\
\hline & DEXY CO KIDS \\
\hline & ALEXANDAR COSMETICS \\
\hline & LILLY DROGERIE \\
\hline & EXTREME INTIMO \\
\hline & GIGATRON \\
\hline & TEHNOMANIJA \\
\hline
\end{tabular}




\section{Marija BORANIJAŠEVIĆ}

Academy of Technical and Educational Applied Studies

The names of the cafés and stores above were only to illustrate the phenomenon of a large influence of English and the use of Latin alphabet mainly. Therefore, we will not go deeper into analysis of this issue, as it would largely exceed the volume of this paper. However, it should be noted that Serbian and Cyrillic are marginalized in many aspects of everyday life.

\section{The Serbian Language and Cyrillic in the Media}

Not only is everyday life in Serbia affected by English, but the media are also full of these examples. Daily newspapers and weekly or monthly magazines contain a high amount of anglicisms, and not only those which have been in use in Serbian for some time, but also those which keep entering the Serbian language on a daily basis, gradually changing the natural expression of Serbian. ${ }^{2}$ This phenomenon can also be witnessed in TV broadcasts. English grammar and orthography rules are mirrored, so headlines, for example, are often written according to the rules of English orthography, with all the words beginning with capital letters. Quotation marks are also used according to the rules of English grammar, not Serbian. Moreover, English spelling is often used instead of a transcribed version of a proper noun, for instance someone's name or last name. This phenomenon is omnipresent in movie subtitles. ${ }^{3}$ Besides all this interference of English into Serbian, it seems that the most serious one is the use of Latin alphabet instead of Cyrillic. Therefore, the research in this paper is directed towards the use of Cyrillic in the daily newspapers and national TV channels in the Republic of Serbia.

In the table below there is a list of the national daily papers. In the left column there are the papers printed in Cyrillic, while the newspapers presented in the right column are printed in Latin alphabet.

2 More about this topic in: Boranijašević, 2017, Boranijašević 2018 (a) and Boranijašević, 2018 (b).

3 This is just one aspect of the problems appearing in movie subtitles. The other is certainly the very translation which is often poor. However, it is not the topic of this paper, and we are just using this example for illustration purposes only. 


\begin{tabular}{|c|c|}
\hline CYRILLIC & LATIN ALPHABET \\
\hline POLITIKA & BLIC \\
\hline VEČERNJE NOVOSTI & DANAS \\
\hline SPORTSKI ŽURNAL & ALO! \\
\hline & INFORMER \\
\hline & SRPSKI TELEGRAF \\
\hline & KURUR \\
\hline & OBJEKTIV \\
\hline & NOVA \\
\hline & KATRIN \\
\hline & METRO \\
\hline & OPPOSITE SHOES AND BAGS \\
\hline & DEXYKIDS \\
\hline & DEX KIDS \\
\hline & ALEXILLY DROGERIE \\
\hline & EXTREME INTIMO \\
\hline & GIGATRON \\
\hline & TEHNOMANIJA \\
\hline
\end{tabular}

As it can be seen, only three daily papers are printed in Cyrillic, Sportski žurnal being published by Politika publishing company, while the eight others are published in Latin alphabet.

When it comes to TV stations, the situation is similar. Very few stations use Cyrillic, while all the others use Latin alphabet. The table below illustrates this point. It offers an overview of the use of Cyrillic and Latin alphabet in the public channels broadcasting nationally and regionally and private channels broadcasting nationally.

\begin{tabular}{|c|c|}
\hline CYRILLIC & LATIN ALPHABET \\
\hline RTS 1 & B92 \\
\hline RTS 2 & HAPPY \\
\hline RTS 3 & PINK \\
\hline RTV 1 & PRVA \\
\hline RTV 2 & \\
\hline
\end{tabular}


It can be seen that all of the public TV stations, three of which broadcast nationally (RTS 1, RTS 2 and RTS 3) and two of which broadcast regionally (RTV 1 and RTV 2) use Cyrillic, while all the private TV stations broadcasting nationally use Latin alphabet. When it comes to TV stations broadcasting regionally or those pay-tv channels, Latin alphabet is mainly used. For example, the whole list of Pink channels is in Latin. Moreover, the very names are in English, such as Pink Classic, Pink Comedy, Pink Romance, Pink Family etc. The same goes for Prva Channels, the names of which are Prva World, Prva Life, Prva Files and similar, or TV stations such as Superstar, Kurir TV, TV K1, Red TV, Vesti, Studio B etc. On the other hand, all of the RTS cable channels are in Cyrillic, with the Serbian names, such as RTS život, RTS muzika, RTS drama, RTS kolo etc. Therefore, the private channels should follow the example of the public national channels using Cyrillic, since the Serbian language and Cyrillic represent an inseparable unity to be cherished as such.

\section{Concluding Remarks}

Language is not only an instrument for communication and understanding among people, but also one of the basic characteristics of cultural identity of one nation, besides the writing itself. Language is "the most magnificent cultural monument that one nation can build for itself" (Petrović, 2014: 26).

Every language possesses a certain number of borrowed words. The Serbian language is no exception to the rule. Therefore, there are plenty of words borrowed from English, French, German, Turkish etc. They have become a part of the Serbian language and have been in use for quite a long time, gradually adjusting to the natural expression of Serbian. The use of these words is justified if there are no words in Serbian to designate an object or notion, which is the reason for their entering Serbian in the first place. However, nowadays there is a completely different trend of English words invading Serbian although there are Serbian equivalents existing. In the beginning, this new vocabulary was limited to IT terminology. However, this phenomenon has spread to all the spheres of human life due to the already mentioned language Anglo-globalization. Therefore, the Serbian language is in danger of gradually losing its natural expression and uniqueness due to the uncontrolled overflow of English words into Serbian, and not only in everyday life, but also in all the different aspects of professional life and the media.

When it comes to the use of Cyrillic, the situation is even more serious. Besides Cyrillic being the national and official writing in the Republic of Serbia, its use nowadays is very limited. Cyrillic, due to the reform of Vuk Stefanović Karadžić, represents an almost perfect alphabet in which one letter corresponds with one sound, which cannot be said for Latin alphabet. Nevertheless, people in Serbia keep using Latin alphabet, giving it priority over Cyrillic. There could be two main reasons for this persisting phenomenon. One of them is probably the totally ungrounded wish to be closer to Europe and the World. If we look close enough, we will notice 
that our neighboring country Bulgaria uses Cyrillic only, and it still has been a part of European Union from 2007, not to mention Russia, one of the World's leaders in the spheres of education, economy and culture. Greece could also be mentioned, as an EU country, using a unique alphabet that no other country uses. This way, they keep their originality and uniqueness, cherishing their rich history and tradition, at the same time being a part of the developed modern world. Therefore, Cyrillic in no way prevents Serbia from being a part of the World. The other reason for so broad use of Latin alphabet could be the legacy of old times and the idea of Yugoslavia and Yugoslav spirit. Back at the times of Yugoslavia, Cyrillic and Latin alphabet were both in official use. However, it is no longer the case, and according to the Constitution of the Republic of Serbia only Cyrillic is in official use. Nevertheless, Latin alphabet keeps being used not only in everyday life, but in the media as well, as the research has shown, not to mention that a large percentage of Serbian citizens use Latin alphabet exclusively. ${ }^{4}$

The results of this research show that Serbian is under a large influence of English, both in the sphere of everyday life and the media, which can be seen in the very names of the cafés and stores and a dominant use of Latin alphabet over Cyrillic. A large number of English words enter Serbian on a daily basis. This phenomenon cannot be compared to the past when foreign words also used to be borrowed in absence of an equivalent in Serbian since it used to be sporadic and justified and did not lead to a massive change in the expression of Serbian. Nowadays, this phenomenon is prevalent and uncontrolled and there is a serious danger of Serbian language gradually losing its original expression and identity. Moreover, Cyrillic is marginalized while representing a unique, almost perfect alphabet. Therefore, this should serve as a warning to all the native speakers of Serbian to think twice before using an English term instead of an existing Serbian one, or rather using Latin alphabet over Cyrillic. This persisting problem should be kept in mind all the time, so the fight for maintenance of the Serbian language and Cyrillic should start on the individual level in order for it to be spread to all the other aspects of life. The Serbian language and Cyrillic represent an exquisite treasure and a sign of cultural identity of Serbian people which should be highly valued and cherished as such.

4 According to the research conducted in 2018, $21.11 \%$ of the Serbian citizens who had been a part of this research use Latin alphabet exclusively, while $33.33 \%$ of them use Cyrillic. In everyday communication Cyrillic is used by $65.56 \%$ of the questionees, while $34.44 \%$ of them use Latin alphabet. When it comes to official correspondence, $45.56 \%$ use Cyrillic, while $54.44 \%$ of them use Latin alphabet. The results of this research are not only surprising but also inappropriate, since more than a half of the examinees use Latin alphabet in formal correspondence, while only Cyrillic is in official use in the Republic of Serbia. (Boranijašević, 2018b) 


\section{Marija BORANIJAŠEVIĆ}

\section{LITERATURE}

1. Boranijašević Marija (2017): Neopravdana upotreba anglicizama u novinarskom diskursu, primer dnevne štampe. In: ed. Miletić, M. Godišnjak fakulteta za kulturu i medije „Komunikacije, mediji, kultura”, no. 9; Beograd: Univerzitet „Džon Nezbit”; p: 61-78.

2. Boranijašević Marija (2018a): Uljezi u srpskom jeziku: noviji anglicizmi i „kvazianglicizmi" u tekstovima novinskih članaka nedeljnih i mesečnih magazina. In: ed. Miletić, M. Godišnjak fakulteta za kulturu i medije „Komunikacije, mediji, kultura”, no. 10; Beograd: Megatrend univerzitet; p: 145-160.

3. Boranijašević Marija (2018b): Očuvanje srpskog jezika i njegovih obeležja. In: ed. Miletić M, Radonić, M. „Kultura i društveni razvoj” (IV), zbornik radova sa četvrte naučne konferencije „Istraživanje, predstavljanje, zaštita i očuvanje kulturnog nasleđa Srbije i srpskog naroda"; Beograd: Megatrend univerzitet; p: 125-135.

4. Bugarski Ranko (1972): Jezik i lingvistika; Beograd: Nolit.

5. Bugarski Ranko (1983): Lingvistika o čoveku; Beograd: Prosveta.

6. Bugarski Ranko (1996): Uvod u opštu lingvistiku; Beograd: Čigoja.

7. Janićijević Jasna (2000): Komunikacija i kultura; Sremski Karlovci, Novi Sad: Izdavačka knjižarnica Zorana Stojanovića.

8. Petrović Tihomir (2014): Umeće govorenja; Novi Sad: Prometej.

9. Prćić Tvrtko (2005): Engleski u srpskom; Novi Sad: Zmaj.

10. Rot Nikola (2004): Znakovi i značenja; Beograd: Plato. 


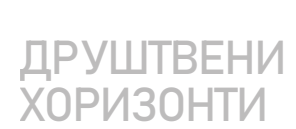

240

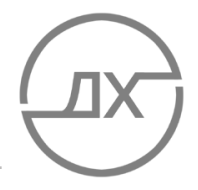

Марија БОРАНИЈАШЕВИЋ

Академија техничко-васпитачких струковних студија Ниш

\section{СРПСКИ ЈЕЗИК \\ И ЋИРИЛИЦА \\ У СВАКОДНЕВНОМЖИВОТУ \\ И МЕДИЈИМА}

Апстракт: Предмет истраживања у овом раду је употреба српског језика и ћирилице у свакодневном животу и медијима. Савремени начин живота и модерни токови увелико утичу на српски језик и употребу ћириличког писма услед свеприсутности енглеског језика у свим сферама наших живота, чији утицај је довео до феномена под називом језичка англоглобализација. Чини се да се српски језик, под снажним утицајем енглеског језика, постепено мења. Ова промена се не дешава само у сфери свакодневног живота, већ и у свим сферама професионалног живота. Поред снажног утицаја енглеског језика који се огледа у називима фирми, продавница, кафића и слично, још један проблем привлачи пажњу, а то је веома ограничена употреба ћирилице како у свакодневном животу, тако и у медијима. Предмет анализе у раду представљају имена кафића и присуство ћириличког писма, као и употреба ћирилице у медијима - дневним новинама и ТВ каналима. Резултати показују да је ћирилица у прилично ограниченој употреби, док је латиници дат примат како у свакодневном животу, тако и у медијима.

КљУчне речИ: ЕНГЛЕСКИ ЈЕЗИК, СРПСКИ ЈЕЗИК, СВАКОДНЕВНИ ЖИВОТ, МЕДИЈИ, ЋИРИЛИЦА, ЛАТИНИЦА. 